\title{
Modelling Three-Dimensional Winds on a NW Pacific Region of Mexico Using Boundary-Fitted Grids
}

\author{
Carlos R. Torres-Navarrete \\ Universidad Autónoma de Baja California, Instituto de Investigaciones Oceanológicas, Centro Nacional de Datos Oceanográficos, \\ Ensenada, México
}

Email: ctorres@uabc.edu.mx

How to cite this paper: Torres-Navarrete, C.R. (2017) Modelling Three-Dimensional Winds on a NW Pacific Region of Mexico Using Boundary-Fitted Grids. Open Journal of Marine Science, 7, 109-123. http://dx.doi.org/10.4236/ojms.2017.71009

Received: October 14, 2016

Accepted: January 9, 2017

Published: January 12, 2017

Copyright $\odot 2017$ by author and Scientific Research Publishing Inc. This work is licensed under the Creative Commons Attribution International License (CC BY 4.0).

http://creativecommons.org/licenses/by/4.0/

(c) (i) Open Access

\begin{abstract}
In this study, the momentum equations describing an atmospheric flow over a NW Pacific region of Mexico are solved numerically. In order to capture the complex flowtopography interactions with detail, a combination of a numerical wind model in full $3 \mathrm{D}$ curvilinear coordinates, along with a high resolution boundary-fitted grid is used. Boundary conditions were obtained from ten years (2002-2012) of measured offshore wind data. Prevailing winds from April to September during that period of observations were selected for the simulations. For the cases analyzed, it was found that at the points of the study region (PSS, PSM, PM), wind speed increased about $10 \%$ to $20 \%$ of its offshore values, while inland they decreased about $86 \%$ to $96 \%$. This spatial behavior agreed very well with the observed local winds. A coastal jet (CJ), $35 \mathrm{~km}$ long with speeds about $1.5-2 \mathrm{~m} / \mathrm{s}$, emanating from PSS was found for NNW winds. Modeled winds were also used to compute wind stresses, wind stress curl, and CUI fields. Wind stress values agreed very well to those reported in the literature. High values of wind stress curl, and CUI were found at the lee of the points (PSS, PSM, $\mathrm{PM})$. Indirect estimations of sea surface currents were about $15-20 \mathrm{~cm} / \mathrm{s}$ offshore and $5-10 \mathrm{~cm} / \mathrm{s}$ at the coast.
\end{abstract}

\section{Keywords}

Boundary-Fitted Grids, Upwelling Index, Wind Modelling

\section{Introduction}

Orographic modification of stably stratified air flow past a topographic obstacle has been the subject of numerous investigations. Previous research has focused on many aspects of idealized low-level three-dimensional flow in the vicinity of isolated topography [1] [2] [3] and associated downstream wake dynamics [4] [5] [6], while studies 
on realistic topography have been performed in other parts of the world by several authors such as [7]-[12] among others. Regionally, while a great deal of attention has been paid to modeling wind driven ocean currents, the related problem of marine air flow over land has received considerably less attention. Thus, the present contribution represents one of the firsts modelling efforts to study wind effects at high resolution in the region (see Figure 1); moreover, use of boundary-fitted grids captures the complexity of the orography of the study site. The study of flow modification by orography in this region is a challenge for a variety of reasons that include a combination of complex topography, wind variability, and associated boundary-layer processes.

Ensenada city is located on the NW Pacific Coast of Mexico, bordered on the North and East by variable orography, with mountains $1500 \mathrm{~m}$ tall, South by Point Banda, PB (a cape, approximately $8 \mathrm{~km}$, long), and West by the Pacific Ocean and a small pair of islands (Islas de Todos Santos, ITS) (Figure 1). The region is an example of a developing urban area located in complex terrain where most of the population is settled along the coast.

The purpose of this investigation is to explore the dynamics of flow past complex topographic obstacles with special emphasis on the formation of lower-boundary jet streams emanating from capes and points such as Point Salsipuedes (PSS), Point San Miguel (PSM), Point Morro (PM) and Point Banda (PB). Particularly, we are interested in the response of winds within the study region to coastal topographic forcing of the marine airflow. With this aim in mind, we conducted a series of numerical experiments using the General Curvilinear Atmospheric Model (GCAM) [13] [14] with $100 \mathrm{~m}$
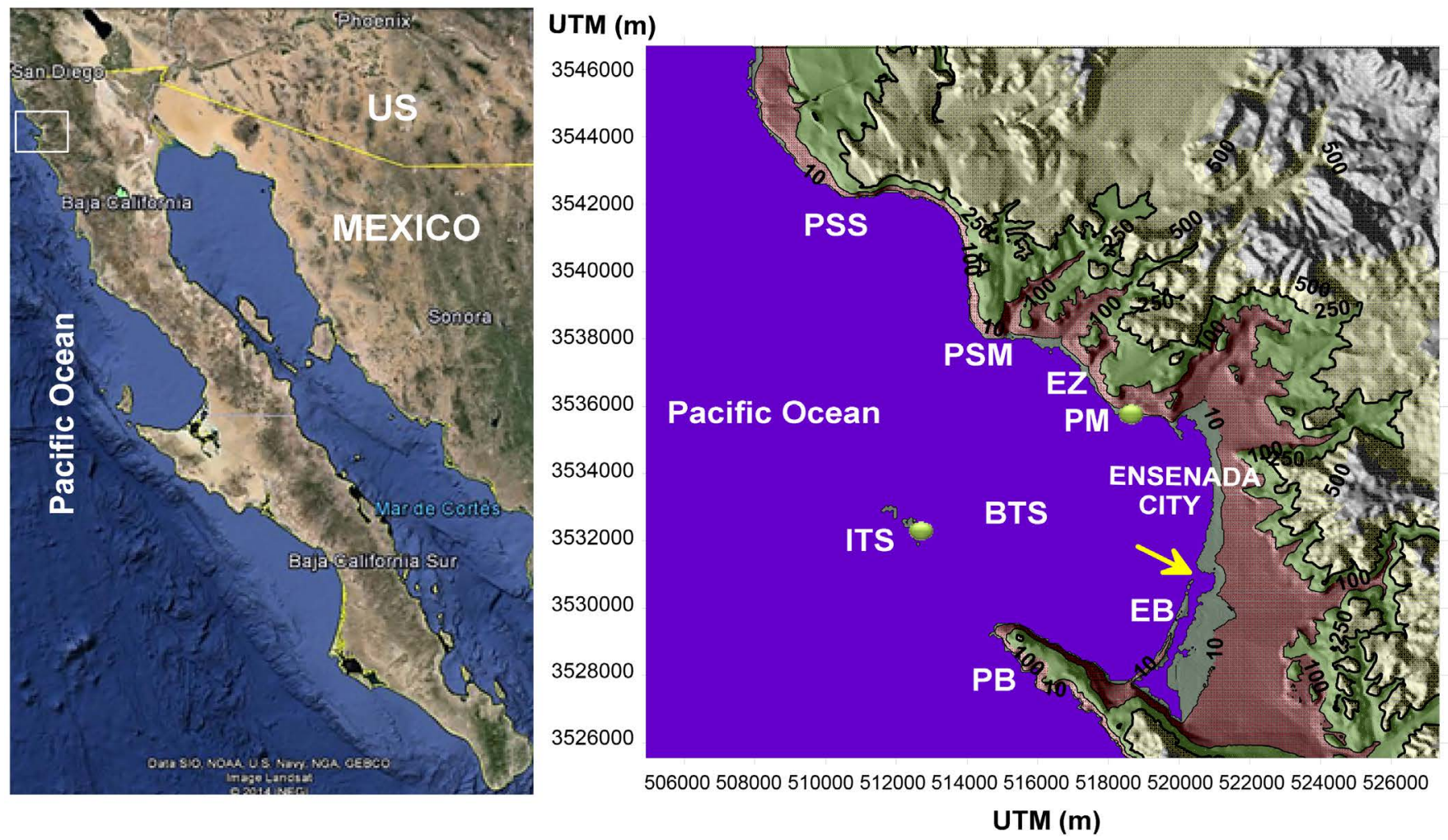

Figure 1. (a) Baja Penìnsula, (b) a zoom showing the complex orography of the study site; contour elevation (in black) is in meters and the yellow dots mark the sites of wind monitoring stations. 
horizontal grid resolution. The experiments were performed for the most persistent winds and the results were compared with available observations. Subsequently, they were used for calculating the wind stress, wind stress curl and other variables of biological interest.

\section{Observations}

The Institute of Oceanological Research (IIO) from Autonomous University of Baja California (UABC), maintains several meteorological stations in the Ensenada area. The locations of two of them, ITS (island station) and PM (coastal station), are shown in Figure 1. Of interest for this study are the winds from April to September, in which the climate over the region is warm, dry and stable due to the strong subtropical high over the adjacent North Pacific Ocean [15]. During this period, winds blow steadily alongshore from the northwest and the large-scale sinking motion almost completely suppresses precipitation [15]. Monthly averages of available data from 2005-2012 for this month's period are presented in Table 1 . At ITS station, winds come from $287^{\circ}$ to $330^{\circ}$;

Table 1. Monthly wind average and direction at ITS and PM stations for several months from 2005-2012. (a) ITS, (b) PM.

(a)

\begin{tabular}{ccccccc}
\hline \multicolumn{7}{c}{ VELOCITY (m/s) } \\
\hline YR & APR & MAY & JUN & JUL & AUG & SEP \\
\hline 2005 & 2.17 & 1.95 & 2.91 & 2.95 & 3.03 & 3.09 \\
2006 & 3.76 & 2.87 & 3.12 & 3.00 & 3.22 & 3.36 \\
\hline YR & \multicolumn{7}{c}{ DIRECTION } & & & \\
\hline 2005 & APR & MAY & JUN & JUL & AUG & SEP \\
\hline 2006 & $322^{\circ}$ & $312^{\circ}$ & $305^{\circ}$ & $307^{\circ}$ & $318^{\circ}$ & $330^{\circ}$ \\
\hline
\end{tabular}

(b)

\begin{tabular}{ccccccc}
\hline \multicolumn{7}{c}{ VELOCITY (m/s) } \\
\hline YR & APR & MAY & JUN & JUL & AUG & SEP \\
\hline 2006 & 2.83 & 2.67 & 2.57 & 2.72 & 2.69 & 2.33 \\
2008 & 2.63 & 2.86 & 2.46 & 2.33 & 2.47 & 2.19 \\
2010 & 2.70 & 2.70 & 2.40 & 2.50 & 2.30 & 2.1 \\
2011 & 2.61 & 2.79 & 2.71 & 2.30 & -- & 2.01 \\
2012 & 2.39 & 2.64 & 2.56 & 2.43 & 2.22 & 1.82 \\
\hline & & & & & \\
\hline YR & APR & MAY & JUN & JUL & AUG & SEP \\
\hline 2006 & $310^{\circ}$ & $275^{\circ}$ & $267^{\circ}$ & $271^{\circ}$ & $279^{\circ}$ & $269^{\circ}$ \\
2008 & $301^{\circ}$ & $280^{\circ}$ & $263^{\circ}$ & $265^{\circ}$ & $269^{\circ}$ & $265^{\circ}$ \\
2010 & $296^{\circ}$ & $282^{\circ}$ & $255^{\circ}$ & $259^{\circ}$ & $264^{\circ}$ & $255^{\circ}$ \\
2011 & $297^{\circ}$ & $294^{\circ}$ & $279^{\circ}$ & $266^{\circ}$ & -- & $275^{\circ}$ \\
2012 & $282^{\circ}$ & $271^{\circ}$ & $270^{\circ}$ & $276^{\circ}$ & $273^{\circ}$ & $267^{\circ}$ \\
\hline
\end{tabular}


estimated maximum velocity was $3.90 \mathrm{~m} / \mathrm{s}$; similar wind velocity estimates have been reported previously [16] [17] [18] [19] [20]. At the coastal PM station, the direction range is modified to $255^{\circ}-310^{\circ}$, while maximum wind velocity decreases by approximately $26 \%$. It is worth to mention that farther offshore, the surface wind speeds derived from SSM/I satellite data range from $5-6 \mathrm{~m} / \mathrm{s}$ [21] [22].

\section{Computational Methods}

The numerical simulations employ the General Curvilinear Atmospheric Model (GCAM, [13] [14]). GCAM is a non-hydrostatic, non-linear, curvilinear full 3D primitive variables model that solves the momentum equations using boundary-fitted grids. It utilizes a finite-difference discretization and a semi-implicit time integration scheme to simulate the temporal development of a stratified flow over irregular orography in a rotating system.

The full derivation of the model's equations can be found in [23] [24]; here, they are described briefly. The set of perturbed dimensionless equations to be solved is given by [13];

$$
\begin{gathered}
\mathrm{Du} / \mathrm{D} t=-\nabla p-\left(1 / R_{0}\right)(v \mathrm{i}-u \mathrm{j})-\left(1 / F^{2}\right) \rho \mathrm{k}+(1 / R e) \nabla^{2} \mathrm{u} \\
\mathrm{D} \rho / \mathrm{D} t=0 \\
\nabla^{2} p=-\left(1 / F^{2}\right) \nabla \cdot(\rho \mathrm{k})-\nabla \cdot[(\mathrm{u} \cdot \nabla) \mathrm{u}]+(1 / R e) \nabla^{2} D-\partial D / \partial t+(1 / R o) \nabla \cdot(v \mathrm{i}-u \mathrm{j})
\end{gathered}
$$

where bold letters represent vectors. This way, $u=(u, v, w)$ is the velocity vector; $\mathrm{i}, \mathrm{j}$ and $k$ are the unit vectors in the $x, y$, and $z$ coordinates respectively; $p$ is the pressure; $\rho$ is the density of the air and $D(=\nabla \cdot u)$ represents the divergence. The dimensionless numbers are the Reynolds number, $\operatorname{Re}\left(=U L / A_{H}\right)$, the Froude number, $F(=U / N h)$ and the Ross by number $R o(=U / f L)$, where $U, L$ and $h$ are typical velocity, length and height scales, respectively, $A_{H}$ is the eddy viscosity coefficient, $f(=2 \Omega \sin \varphi)$ the coriolis parameter and $N^{2}=\left(-g / \rho_{0}\right) \partial \rho / \partial z$ is the Brünt-Väisälä frequency. As it is noted, in primitive variables, unknowns are $(u, \rho, p)$ as indicated by Equations (1)-(2), while Equation (3) for $p$ substitutes the incompressibility condition $\nabla \cdot u=0$.

As described in [13], the set of governing equations is transformed from Cartesian to Curvilinear coordinates (i.e. from physical $(x, y, z)$ domain to computational $(\xi, \eta, \zeta)$ domain and then solved subject to initial and boundary conditions. On solid boundaries $u=0$, with no flux of density, $\nabla \rho \cdot n=0$ (where $n$ is the unit normal vector), while for $p$, the boundary condition is determined by substituting $u=0$ into the transformed momentum Equation (3).

The geometry of the study site is well captured by using a three-dimensional boundary-fitted grid. The domain consists of $446 \times 420 \times 11(\xi \times \eta \times \zeta)$ grid points that extends $45 \mathrm{~km}$ and $42 \mathrm{~km}$ with $100 \mathrm{~m}$ horizontal resolution in $x$ and $y$ respectively, and 11 vertical layers covering $3000 \mathrm{~m}$ with $10 \mathrm{~m}$ minimum mesh size in $z$. The ground level grid $(\zeta=1)$ along with several vertical grids of the physical domain is shown in Figure 2 .

Simulations were performed for four different directions of incident wind: a) $330^{\circ}, b$ ) $315^{\circ}$, c) $300^{\circ}$ and $\left.d\right) 287^{\circ}$, with fixed $U=6 \mathrm{~m} / \mathrm{s}$ [21] [22]; background stratification was taken as $N=0.01 \mathrm{~s}^{-1}$ (which is a typical value for the atmosphere [25] [26]), and for the 


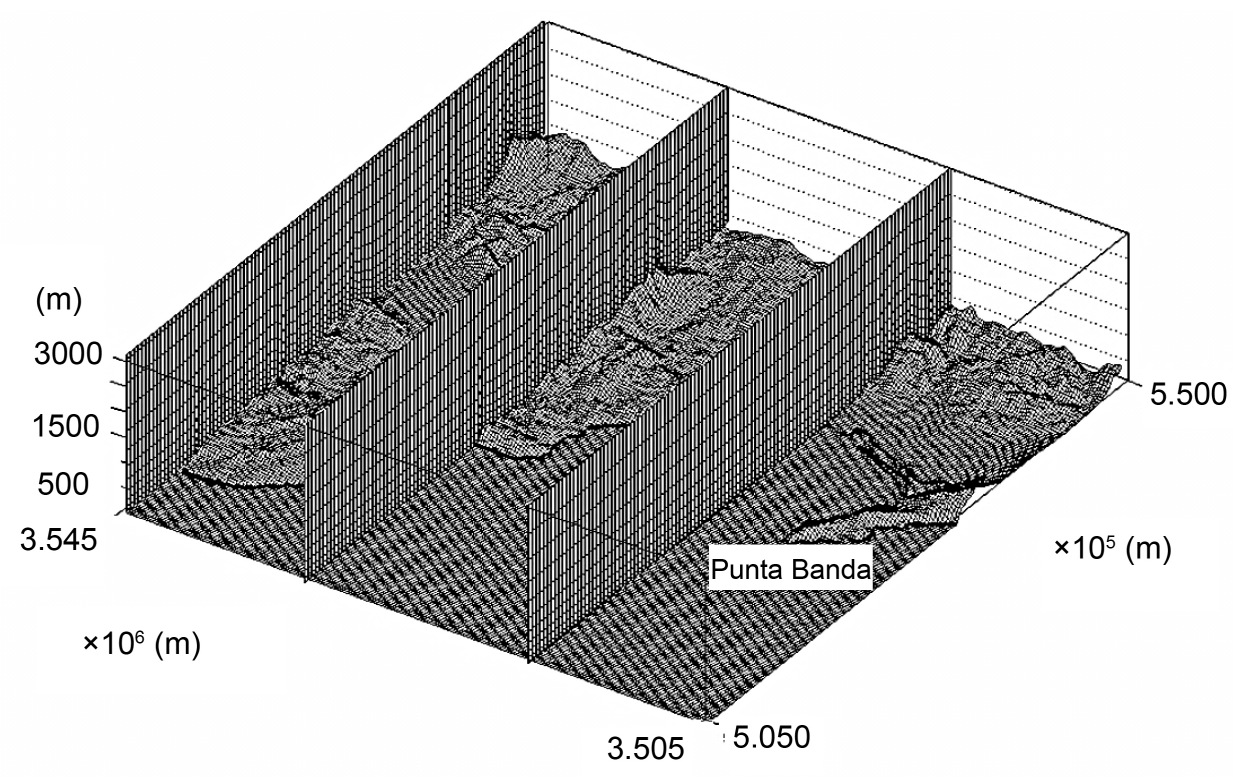

Figure 2. The grid in physical space.

eddy viscosity coefficient we chose the value $A_{H}=2.1 \times 10^{-3} \mathrm{~m}^{2} / \mathrm{s} \quad$ [6]. The Froude number, based on a $10^{2} \mathrm{~m}$ mountain height, was $F=6$, while $R e=5.71 \times 10^{6}$. Rotation was not dynamically significant in these simulations as the calculated Ross by number was $R o>1$.

In all the simulations the fluid started impulsively from rest, and several inertial periods were necessary until the fluid adjusted to this impulsive start. Nearly steady solutions, defined by the convergence criterion: $\left|f^{n+1}-f^{n}\right|_{\max } /\left(f_{\max }^{n}-f_{\min }^{n}\right) \leq 10^{-4}$, where $n$ is the time step and $f$ represents any one of $u, p$ or $\rho$, were obtained at dimensionless time, $t$, between 40 and 60 ; the dimensionless time increment for the simulations was set to $\Delta t=0.001$.

For each simulation, an estimate of the surface wind stress was calculated according to the bulk formula [27]:

$$
\tau=\left(\tau_{x}, \tau_{y}\right)=\rho_{a} C_{D}\left[\left|\mathrm{~W}_{10}\right| U_{10},\left|\mathrm{~W}_{10}\right| V_{10}\right],
$$

where $\tau_{x x} \tau_{y}$ denote the eastward and northward components of stress, $\rho_{a}$ is the surface air density which was considered to have a constant value of $1.22 \mathrm{~kg} / \mathrm{m}^{3}, W_{10}$ is the observed wind speed, and $U_{10}$ and $V_{10}$ are the eastward and northward components of the wind velocity measured at a height of $10 \mathrm{~m}$. The empirical drag coefficient $C_{D}$, referenced to the $10 \mathrm{~m}$ level, was given a constant value of 0.0013 [28].

Important for biology is the wind stress in relation to upwelling-downwelling generation zones through the Ekman pumping $\left(W_{E}\right)$, and the coastal upwelling index (CUI). Wind stress curl, $(\nabla \times \tau)$, derived from wind simulations, was used to calculate $W_{E}$ according to [29]:

$$
W_{E}=(\nabla \times \tau) / f \rho_{w},
$$

where $\rho_{w}$ is seawater density (taken as $1024 \mathrm{~kg} / \mathrm{m}^{3}$ ) and $f$ the Coriolis parameter. This, way the effect of wind on ocean circulation and upwelling/downwelling generation can be assessed. 
The coastal upwelling index (CUI; $\mathrm{m}^{3} / \mathrm{s}$ per $100 \mathrm{~m}$ of coast) was estimated by using the outputs from the model using the relation [30];

$$
\mathrm{CUI}=\left(\tau_{a} / f \rho_{w}\right) \times 100,
$$

where $\tau_{a}$ is alongshore wind stress within $100 \mathrm{~m}$ of the coastline.

Finally, an estimation of ocean surface current velocity, $u_{\mathcal{S}}$ generated by winds is given by the relation $u_{s}=0.875\left(C_{D}\right)^{1 / 2} w_{10} ; C_{D}=1.5 \times 10^{-3}$ [31]. For example, wind velocities of $10 \mathrm{~m} / \mathrm{s}$ would generate a surface ocean current of $u_{s}=34 \mathrm{~cm} / \mathrm{s}$.

\section{Results and Discussion}

Simulated $10 \mathrm{~m}$ winds are presented in Figure 3. The presence of the coast and mountainous topography rising quickly from the ocean induces irregularities of local winds producing zones of $>6 \mathrm{~m} / \mathrm{s}$ velocity (in yellow) at PSS, PSM and PM (Figures 3(a)-(c)). Inland, the wind spatial distribution corresponds closely to the orography; resulting in weak winds with velocities $<3 \mathrm{~m} / \mathrm{s}$ in the lee of the mountains (see also Figure 1(b)). Offshore, wind velocities reach values between $4-5 \mathrm{~m} / \mathrm{s}$. For $330^{\circ}$ and $315^{\circ}$ incoming winds, a $1.5-2 \mathrm{~m} / \mathrm{s}$ a coastal jet, CJ (approximately $35 \mathrm{~km}$ long and $3 \mathrm{~km}$ width) originates in PSS and enters land between PM and EB (Figure 3(a) \& Figure 3(b)); this CJ is reduced in size and limited to a small area around PSS and PSM for $300^{\circ}$ and $287^{\circ}$ incoming winds (Figure 3(c) \& Figure 3(d)). It is apparent that PSS, PSM and PM terrain features not only act to block or redirect the general flow near the coast; but also they play a key role in the establishment of the CJ.

The structure of the $\mathrm{CJ}$ is clearly elucidated through the vorticity field. Figure 4 presents the vertical component, $\omega_{z z}$ of the vorticity vector $\omega=\left(\omega_{x,} \omega_{y}, \omega_{z}\right)$, where $\omega=$ $\nabla \times u$, corresponding to Figure 3. At the coast, cyclonic vorticity is generated at the major capes of the region such as PSS, PSM and PM, there is also a source of strong anticyclonic vorticity at Point San Miguel (PSM) which probably originates at the canyon connecting Ensenada City and San Antonio village (see Figure 1(b)). Inland, positive and negative vorticity is generated by the complex orography of the region. Once generated, vorticity is advected and diffused leeward.

For winds from $330^{\circ}$ and $315^{\circ}$ there is a wake of positive and negative vorticity that extends several kilometers southeast of PSS (Figure 4(a) \& Figure 4(b)). The eddies in the $\mathrm{EB}$ area are approximately $1.5 \mathrm{~km}$ in diameter. It is important to mention that the jet generated by the $330^{\circ}$ winds enters land at the EB area (Figure 4(a)), while the jet generated by $315^{\circ}$ incoming winds makes landfall by the Ensenada City area (Figure 4(b)). An incipient wake at the lee of ITS is observed for the $300^{\circ}$ and $287^{\circ}$ simulations (Figure 4(c) \& Figure 4(d)).

A vertical view of the $\omega_{y}$ component of the vorticity along the black vertical lines $(1,2$, 3 ) in Figure 4(a) is presented in Figure 5 ( $330^{\circ}$ incoming wind direction). Positive (negative) values represent the seaward (landward) direction, respectively. Over land, positive and negative $\omega_{y}$ values are found between $0-20 \mathrm{~km}$ distances. Over sea, the core of the jet is clearly visible at approximately $19 \mathrm{~km}$ (Figure 5(a)), $26 \mathrm{~km}$ (Figure 5 (b)) and $37 \mathrm{~km}$ (Figure 5(c)), vertical influence is of the order of $500 \mathrm{~m}$. The presence of this $\mathrm{CJ}$ is important from the point of view of transport of physical properties and 


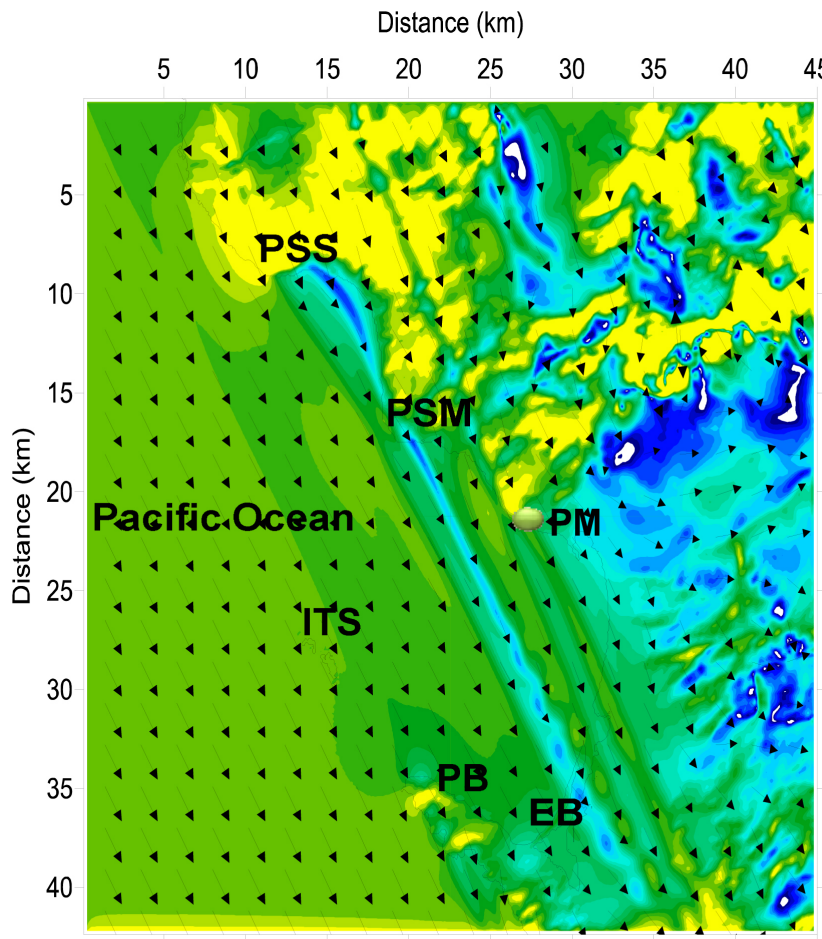

(a)

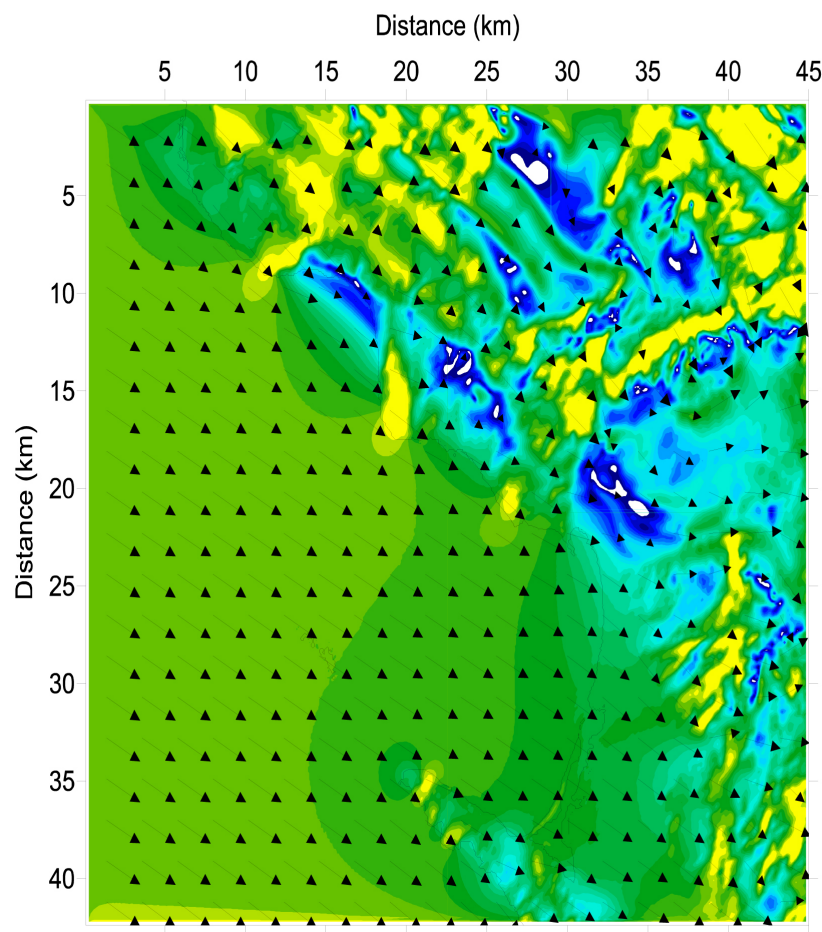

(c)

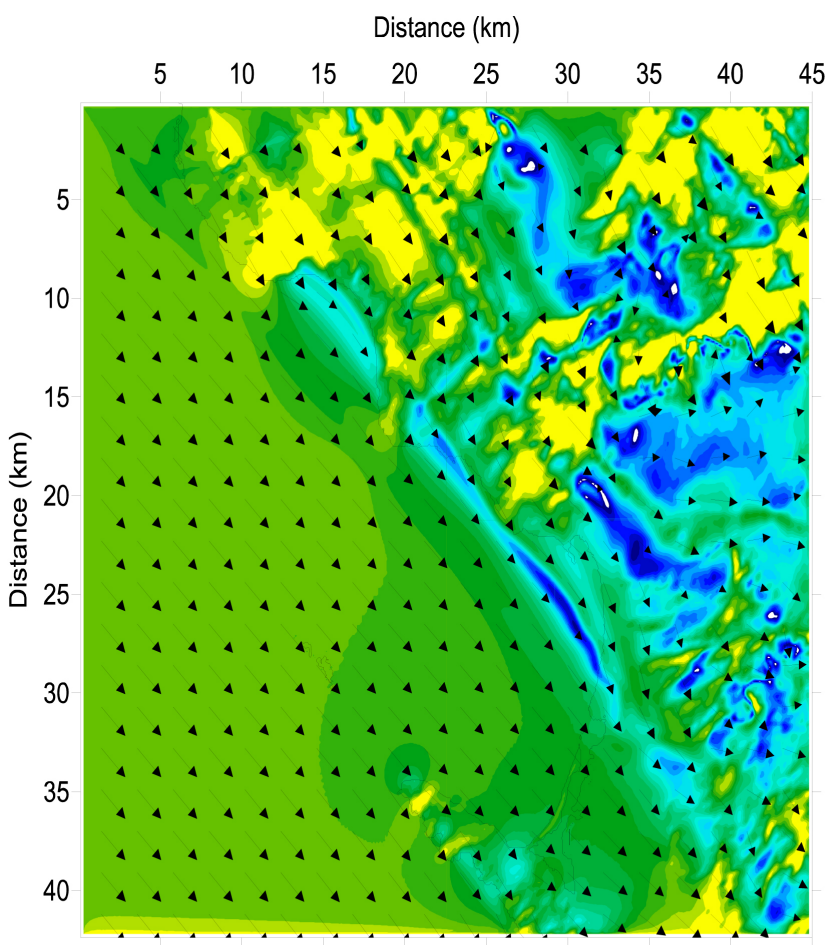

(b)

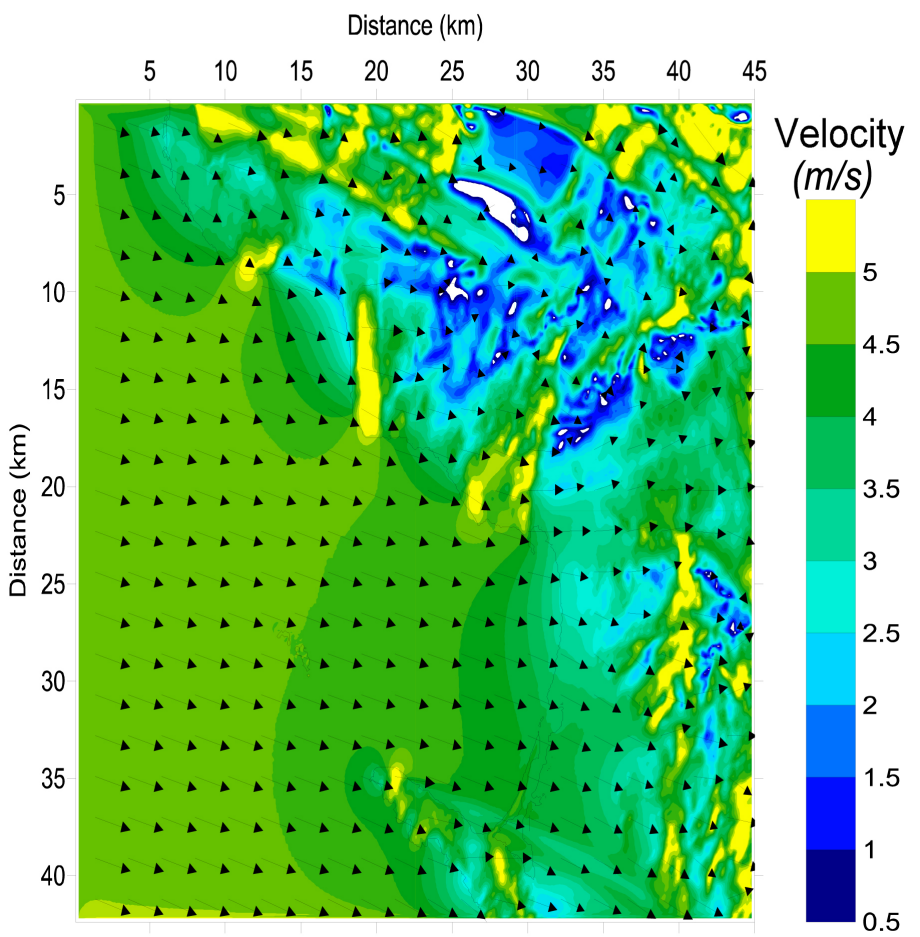

(d)

Figure 3. Simulated $10 \mathrm{~m}$ wind vectors and contours of wind velocity $(\mathrm{m} / \mathrm{s})$ for various incoming wind directions: (a) $330^{\circ}$; (b) $315^{\circ}$; (c) $300^{\circ}$, (d) $287^{\circ}$. Vectors are suppressed every 20 grid points in both the zonal and meridional direction for clarity.

particles from PSS to the urban zone of the study region.

The computed spatial distribution of wind stress $\tau\left(\mathrm{N} / \mathrm{m}^{2}\right)$ and $W_{E}\left(\mathrm{~m}^{3} / \mathrm{s}\right.$ per $\left.100 \mathrm{~m}\right)$ over the sea portion of the study region is presented in Figure 6. As expected, spatial 

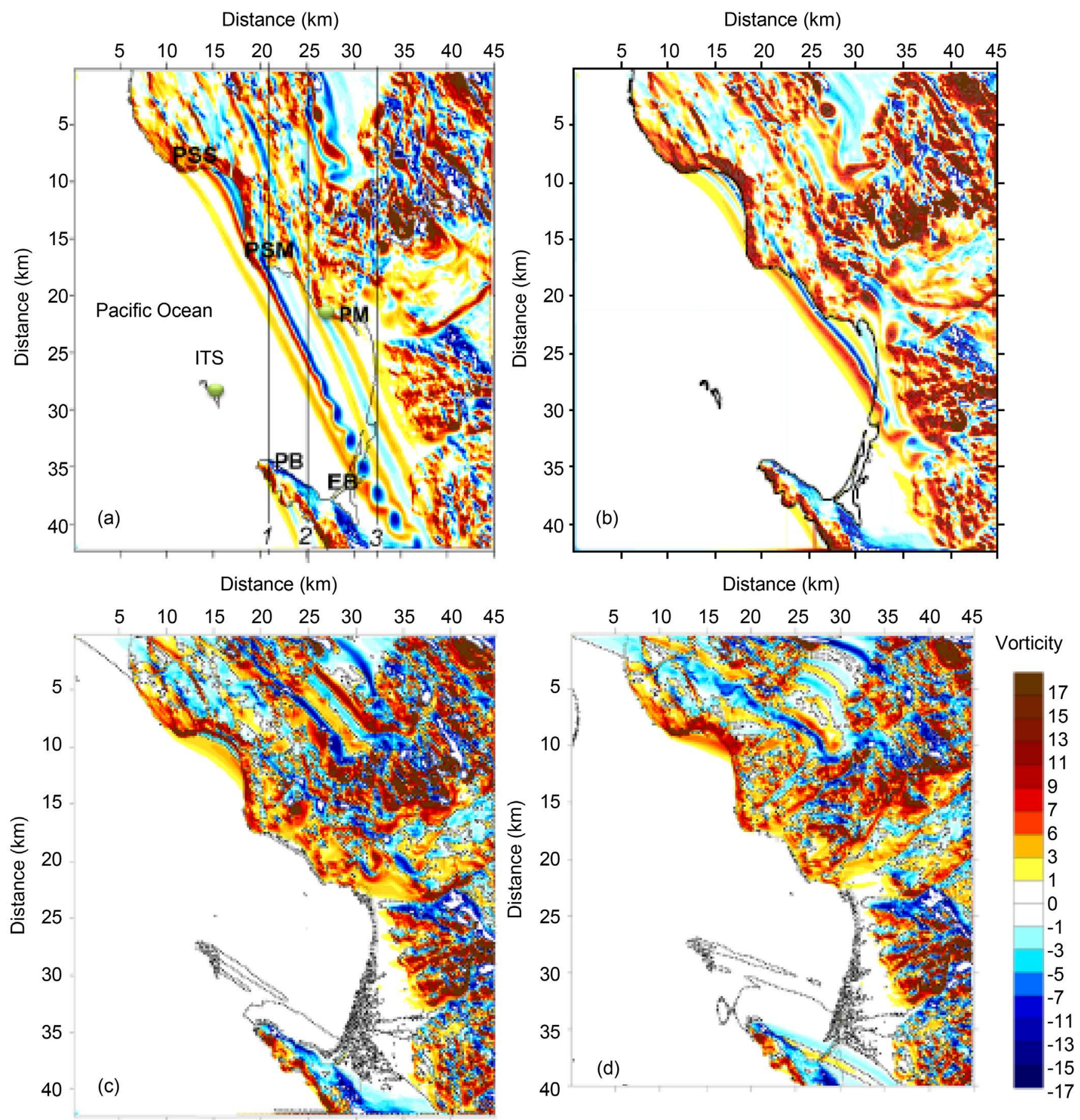

Figure 4. Dimensionless vorticity contours corresponding to Figure 4: (a) $330^{\circ}$; (b) $315^{\circ}$; (c) $300^{\circ}$, (d) $287^{\circ}$. Dotted line in (c) and (d) represents the zero vorticity contours.

stress gradients will induce gradients in the wind stress curl. A spatial inhomogeneity of $W_{E}$ is observed near the coast in response to coastal topographic forcing. Forcing of the marine flow by the curvature of the coastline generates up-welling positive wind stress curl and consequently larger wind stress curl is found in PSS, PSM and PM. Forincoming wind directions $330^{\circ}$ and $315^{\circ}$ the influence of $W_{E}$ extends southeast for several kilometers of the generation point (Figure 6(a) \& Figure 6(b)). Large $W_{E}$ values are 

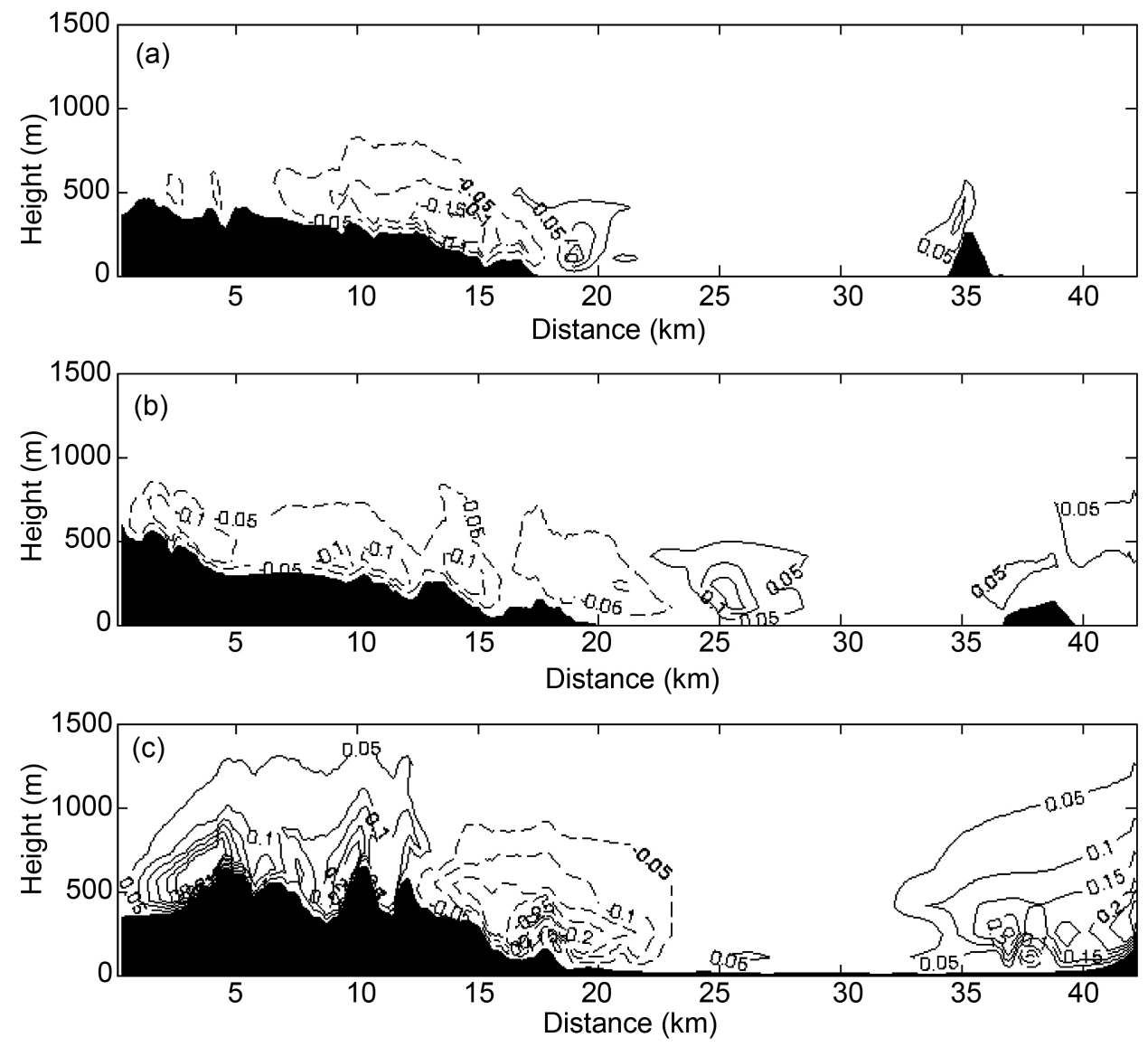

Figure 5. Contours of vorticity along the black lines ( 1 - 3) shown in Figure 6(a) for $330^{\circ}$ winds. (a) line 1; (b) line 2; (c) line 3. Continuous line: positive values; broken line: negative values.

found for $300^{\circ}$ and $287^{\circ}$ incoming wind directions (Figure 6(c) \& Figure 6(d)).

Estimated coastal upwelling index contours (CUI) are shown in Figure 7. Model results indicate that CUI intensifies for wind directions $300^{\circ}$ and $287^{\circ}$ (Figure 7 (c) \& Figure $7(\mathrm{~d})$ ) and tends to diminish slightly for the other simulated cases (Figure 7 (a) \& Figure 7(b)). Maximum CUI values ( 30) were found at the major capes of the study site: PSS, PSM, PM and PB for wind from $300^{\circ}$ and $287^{\circ}$ (Figure 7 (c) \& Figure $7(\mathrm{~d})$ ). There is no adequate way to compare the present results to previous ones since reported CUI values were obtained with very coarse grids. Besides, the wind stress and the wind stress curl can significantly be affected by the orography as noted in [8] [18] [19]; for example Pérez-Brunius et al. [32] found CUI = 12 for Point Banda (PB) using different data sources. CUI values in the range -300 to 300 , obtained from $1^{\circ}$ mesh wind and wind stress data, are reported in [33] for Ensenada Bay. It is worth to mention that fish farming sites placed in the region coincide with the zones of maximum CUI and $W_{E}$ found in this study.

Finally, the estimated ocean surface current velocity, $u_{s}$, generated by the simulated winds, is presented in Figure 8. The effect of the spatial variation of winds on the magnitude of the currents is clearly seen. Offshore, values of $u_{s}$ are of the order $15-20 \mathrm{~cm} / \mathrm{s}$. while estimated $u_{s}$ values are $5-10 \mathrm{~cm} / \mathrm{s}$ at the coast. These values agree remarkably well to those of $5-15 \mathrm{~cm} / \mathrm{s}$ observed at BTS with HF radars for spring and summer [19] 
Distance $(\mathrm{km})$

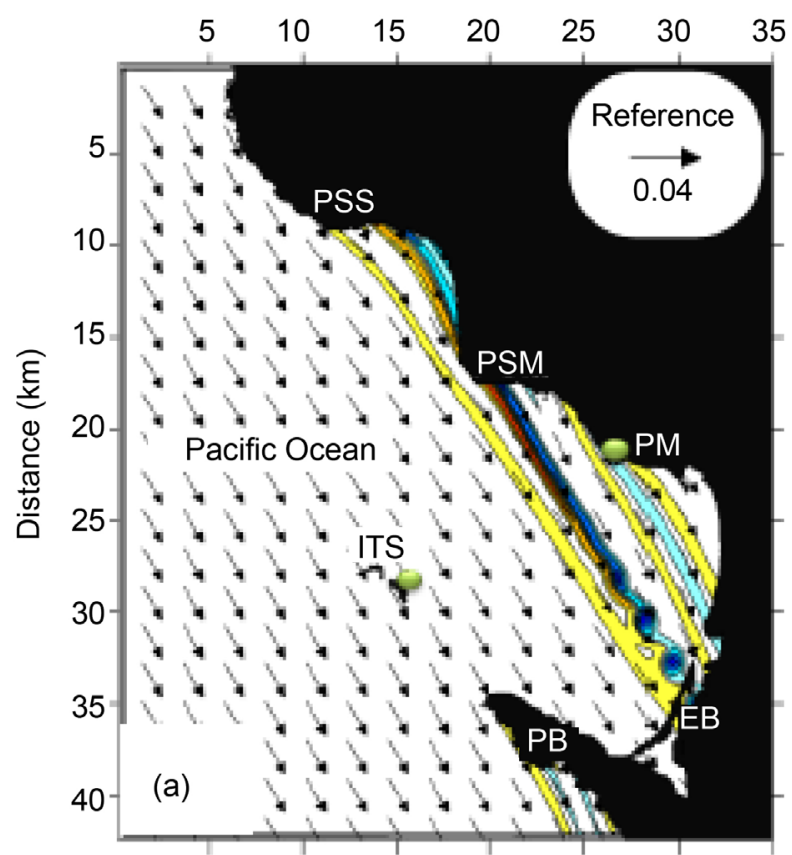

Distance $(\mathrm{km})$

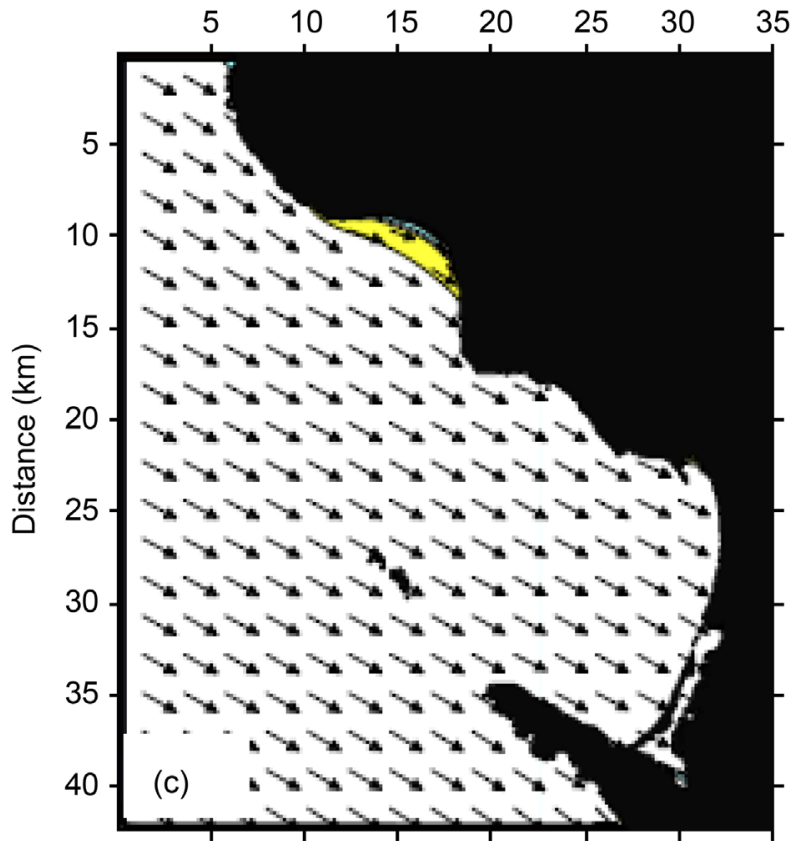

Distance $(\mathrm{km})$

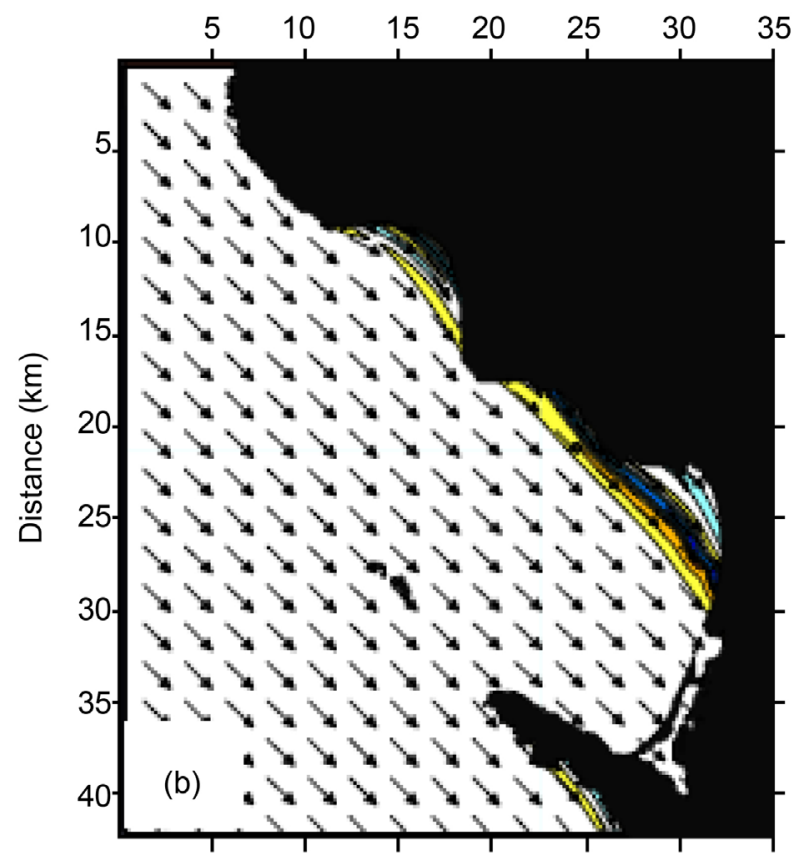

Distance $(\mathrm{km})$

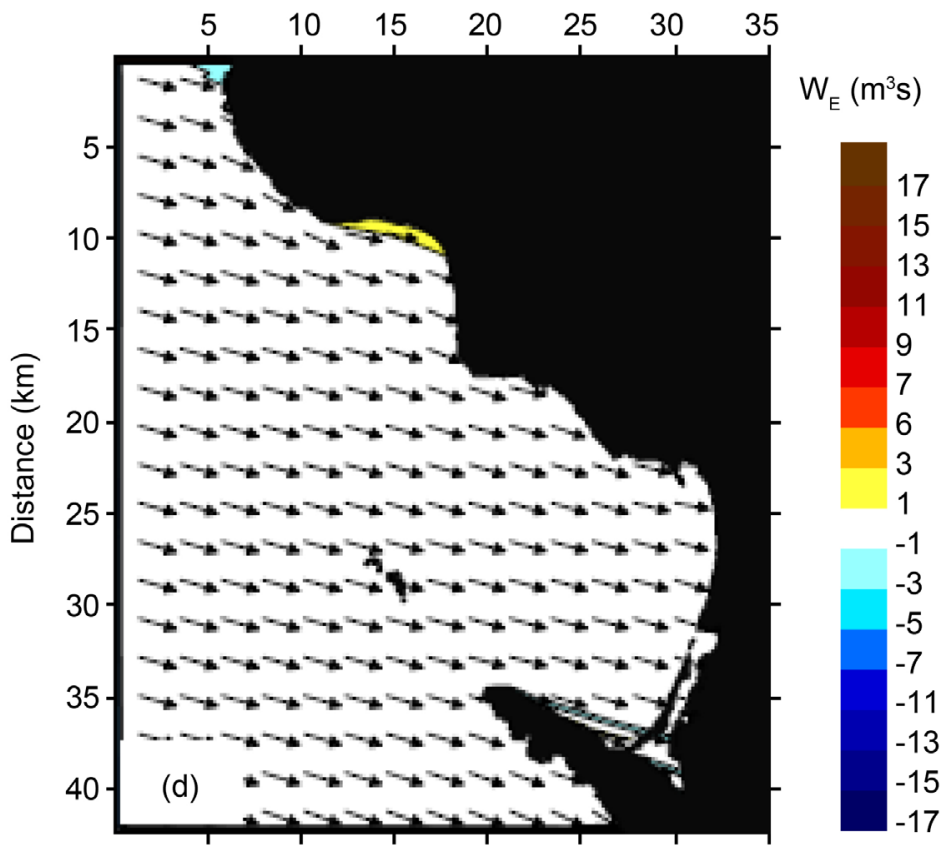

Figure 6. Wind stress $\tau\left(\mathrm{N} / \mathrm{m}^{2}\right.$, arrows) and $W_{E}\left(\mathrm{~m}^{3} / \mathrm{s}\right)$ (colour) distribution for the simulated cases. (a) $330^{\circ}$; (b) $315^{\circ}$; (c) $300^{\circ}$; (d) $287^{\circ}$.

[20]. Also, there is an agreement with previous numerical work which used similar winds to force a 2D ocean model of Ensenada Bay [34].

\section{Conclusions}

The wind circulation at high resolution over the study site has been characterized for the first time. The GCAM model was able to correctly reproduce the magnitude of the wind speed given by the in-situ observations. It was found that at the points, the wind 


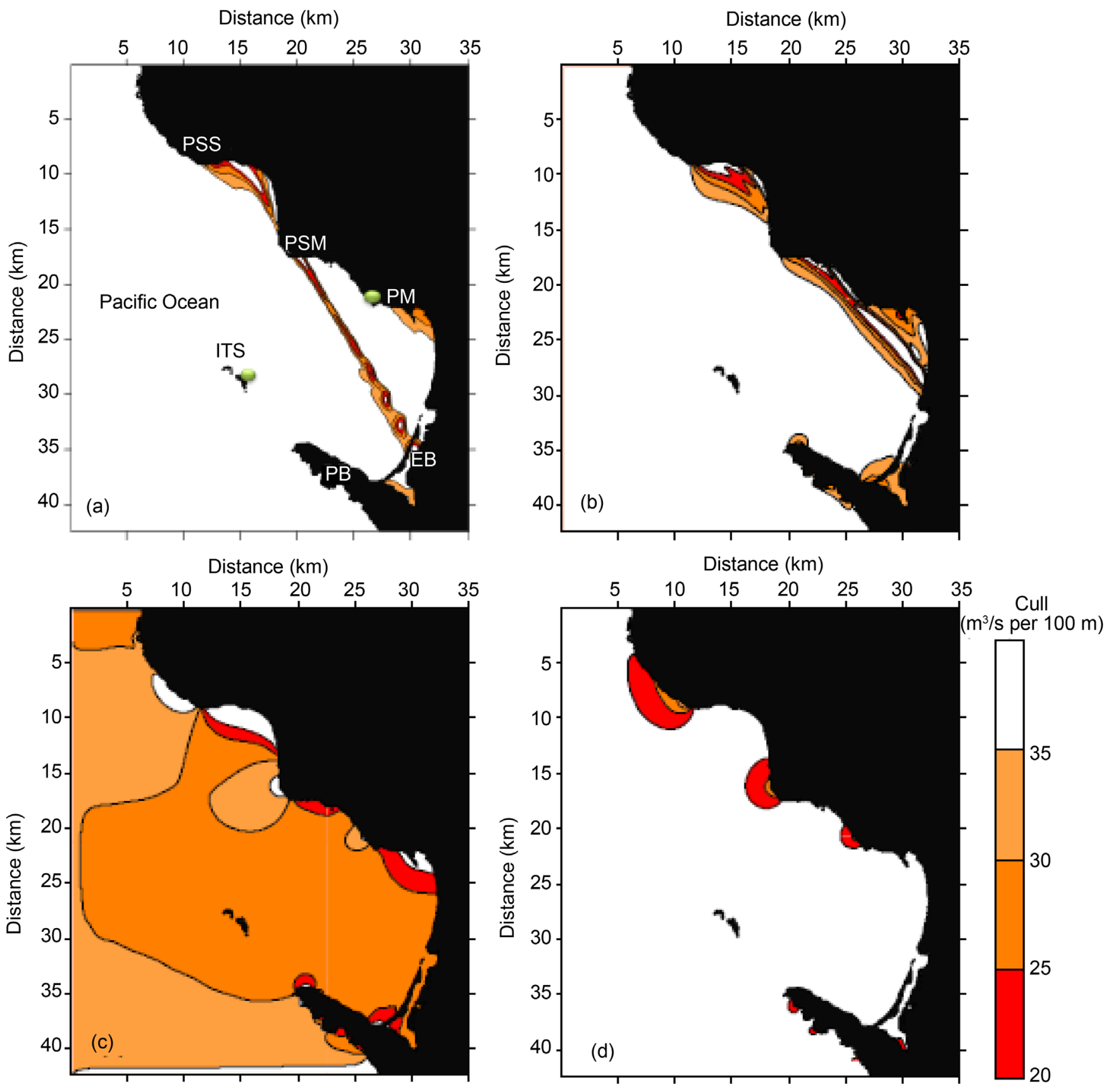

Figure 7. CUI (m³ $/ \mathrm{s}$ per $100 \mathrm{~m})$ distribution: (a) $330^{\circ}$; (b) $315^{\circ}$; (c) $300^{\circ}$, (d) $287^{\circ}$.

speed grows about $10 \%$ to $20 \%$ of its offshore values; inland, they decrease about $86 \%$ and $96 \%$. Estimated wind stress served to identify upwelling/down-welling zones which are important for fisheries farming in the region. Indirect estimates of sea surface currents were about $15-20 \mathrm{~cm} / \mathrm{s}$ offshore and $5-10 \mathrm{~cm} / \mathrm{s}$ at the coast.

Of particular interest is the evolution of a coastal jet (CJ) emanating from PSS and PSM found in this study. This finding is important in relation to microclimate modification and human health as the CJ could transport efficiently air masses of different physical properties as well as particulate matter (such a spore, or toxic agents) from the North to South of the study region. 

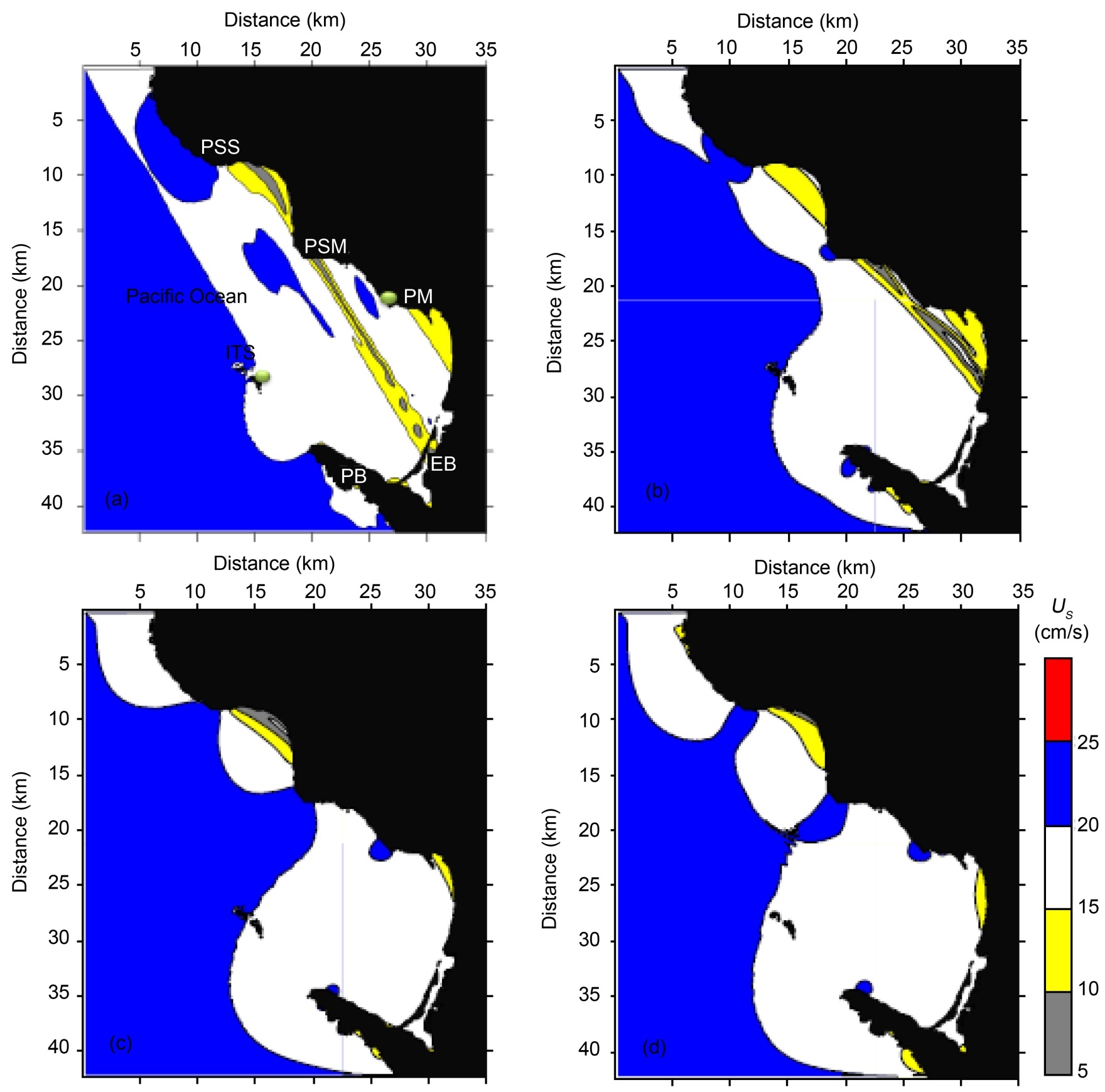

Figure 8. Estimated ocean surface current velocity, $u_{s}(\mathrm{~cm} / \mathrm{s})$ : (a) $330^{\circ}$; (b) $315^{\circ}$; (c) $300^{\circ}$, (d) $287^{\circ}$.

As the number of local synoptic meteorological stations is small, they provide little information on the spatial structure of the winds over the study region. Studies such as this are an excellent source of information to show the conditions over areas that are not represented by measurements, especially those farther offshore and inland. Finally, these results could be an excellent source of information for identifying zones to place wind energy generation turbines and/or fisheries farming sites.

\section{Acknowledgements}

Publication expenses were provided by SEP (Mexico Ministry of Education) through 
the Program for Professional Teacher Development. S. Larios, A. Mejia and E. Gil from the Physical Oceanography Dept. of the Institute for Oceanological Research (IIO-UABC) provided the meteorological data for this study. Computer time was provided by the Mexico National Oceanographic Data Center. B. Inman kindly revised grammar and style. The manuscript was very thoroughly and constructively reviewed by two anonymous reviewers.

\section{References}

[1] Couvelard, X., Caldeira, R.M.A., Araújo, I.B. and Toméc, R. (2012) Wind Mediated Vorticity-Generation and Eddy-Confinement, Leeward of the Madeira Island: 2008 Numerical Case Study. Dynamics of Atmospheres and Oceans, 58, 128-149. https://doi.org/10.1016/j.dynatmoce.2012.09.005

[2] Sun, L. (2011) Large Eddy Simulation of Atmospheric Boundary Layer Flow in Urban Terrain: Implications for Transport of Pollution and Heat. UC San Diego Electronic Theses and Dissertations. http://escholarship.org/uc/item/75w2j7f4

[3] Ross, A.N. and Vosper, S.B. (2005) Neutral Turbulent Flow over Forested Hills. Quarterly Journal of the Royal Meteorological Society, 131, 1841-1862. https://doi.org/10.1256/qj.04.129

[4] Etling, D. (1989) On Atmospheric Vortex Streets in the Wake of Large Islands. Meteorology and Atmospheric Physics, 41, 157-164. https://doi.org/10.1007/BF01043134

[5] Dong, C.M. and McWilliams, J.C. (2007) A Numerical Study of Island Wakes in the Southern California Bight. Continental Shelf Research, 27, 1233-1248. https://doi.org/10.1016/j.csr.2007.01.016

[6] Jimenez, B., Sangra, P. and Mason, E. (2008) A Numerical Study of the Relative Importance of Wind and Topographic Forcing on Oceanic Eddy Shedding by Tall, Deep Water Islands. Ocean Model, 22, 146-157. https://doi.org/10.1016/j.ocemod.2008.02.004

[7] Rasmussen, L.L., Cornuelle, B.D., Levin, L.A., Largier, J.L. and Di Lorenzo, E. (2009) Effects of Small-Scale Features and Local Wind Forcing on Tracer Dispersion and Estimates of Population Connectivity in a Regional Scale Circulation Model. Journal of Geophysical Research, 114, C01012. https://doi.org/10.1029/2008JC004777

[8] Sheridan, P. and Vosper, S. (2012) High-Resolution Simulations of Lee Waves and Downslope Winds over the Sierra Nevada during T-REX IOP 6. Journal of Applied Meteorology and Climatology, 51, 1333-1352. https://doi.org/10.1175/JAMC-D-11-0207.1

[9] Agustsson, H. and Olafsson, H. (2007) Simulating a Severe Windstorm in Complex Terrain. Meteorologische Zeitschrift, 16, 111-122. https://doi.org/10.1127/0941-2948/2007/0169

[10] Chan, P.W. (2009) Atmospheric Turbulence in Complex Terrain: Verifying Numerical Model Results with Observations by Remote Sensing Instruments. Meteorology and Atmospheric Physics, 103, 145-157. https://doi.org/10.1007/s00703-008-0342-3

[11] Hosking, J.S., Bannister, D., Orr, A., King, J., Young, E. and Phillips, T. (2014) Orographic Disturbances of Surface Winds over the Shelf Waters Adjacent to South Georgia. Atmospheric Science Letters, 16, 50-55. https://doi.org/10.1002/asl2.519

[12] Moujane, A., Bentamy, A., Chagdali, M. and Mordane, S. (2014) The Impact of Coastal Orography on Profile Wind. International Journal of Advanced Geosciences, 2, 113-121.

[13] Carlos, T.-N., Sergio, L.-C., Adán, M.-T., Jaime, G.-T., Mariana, M.-C. and Eduardo, G.-S. (2014) Numerical Experiments of Wind Circulation off Baja California Coast. In: Klapp, J. and Medina, A., Eds., Experimental and Computational Fluid Mechanics, Springer, Switzerland, 327-339.

[14] Torres, C.R., Lanz, E. and Larios, S. (2016) Effect of Wind Direction and Orography on 
Flow Structures at Baja California Coast: A Numerical Approach. Journal of Computational and Applied Mathematics, 295, 48-61. https://doi.org/10.1016/j.cam.2015.02.039

[15] Conil, S. and Hall, A. (2006) Local Regimes of Atmospheric Variability: A Case Study of Southern California. Journal of Climate, 19, 4308-4325. https://doi.org/10.1175/JCLI3837.1

[16] Reyes, S., Vogel, G.., Pavía, E. and Parés, A. (1983) Synoptic Effects on Local Winds in Todos Santos Bay: A Case Study. Monthly Weather Review, 111, 1494-1500. https://doi.org/10.1175/1520-0493(1983)111<1494:SEOTLW >2.0.CO;2

[17] Strub, P.T., Allen, J.S., Huyer, A., Smith, R.L. and Beardsley, R.C. (1987) Seasonal Cycles of Currents, Temperatures, Winds, and Sea Level over the Northeast Pacific Continental Shelf: $35^{\circ} \mathrm{N}$ to $48^{\circ} \mathrm{N}$. Journal of Geophysical Research: Oceans, 92, 1507-1526. https://doi.org/10.1029/JC092iC02p01507

[18] Argote Espinoza, M.L., Amador, A. and Morales, C. (1975) Distribución de los parámetros salinidad y temperatura y tenencias de la circulación en la Bahía de Todos Santos. B. C. Memorias de la primera reunión de la CIBCASIO, 3-30.

[19] Cervantes, I.G. (2013) Analysis of Circulation and Dispersion in the Bahia de Todos Santos, Baja California. M.Sci. Thesis, Universidad del Mar, Puerto Angel, Oaxaca, Mexico, 61 p. (In Spanish)

[20] Larrañaga, M.J. (2013) Variability of Surface Circulation in the Bay of Todos Santos, Baja California, Mexico. M.Sci. Thesis, Universidad Autónoma de Baja California, Mexico, 81 p. (In Spanish)

[21] Dorman, C.E. and Koračin, D. (2007) Response of the Summer Marine Layer Flow to an Extreme California Coastal Blend. Monthly Weather Review, 136, 2894-2922.

[22] Koračin, D., Dorman, C.E. and Dever, E.P. (2004) Coastal Perturbations of Marine-Layer Winds, Wind Stress, and Wind Stress Curl along California and Baja California in June 1999. Journal of Physical Oceanography, 34, 1152-1173.

[23] Torres, C.R., Hanazaki, H., Ochoa, J., Castillo, J. and Van Woert, M. (2000) Flow past a Sphere Moving Vertically in a Stratified Diffusive Fluid. Journal of Fluid Mechanics, 417, 211-236. https://doi.org/10.1017/S0022112000001002

[24] Torres, C.R. and Castillo, J.E. (2002) A New 3D Curvilinear Coordinates Numerical Model for Oceanic Flow over Arbitrary Bathymetry. In: Muller-Karger, C.M., Lentini, M. and Cerrolaza, M., Eds., Desarrollos Recientes en Métodos Numéricos, MF, 105-112. (In Spanish)

[25] Ross, A.N. and Vosper, S.B. (2003) Numerical simulations of Stably Stratified Flow through a Mountain Pass. Quarterly Journal of the Royal Meteorological Society, 129, 97-115. https://doi.org/10.1256/qj.02.24

[26] Lohmann, U. (2012) Parcel Buoyancy and Atmospheric Stability. IACETH. http://109.205.171.104/ thomas/eth/5_semester/atmosphaerenphysik_WS_2005_2006/unte rlagen/buoyancy.pdf

[27] Nelson, C.S. (1977) Wind Stress and Wind Stress Curl over the California Current. NOAA Technical Report, Vol. 714 of NOAA Technical Report NMFS SSRF, United States, National Marine Fisheries Service, Department of Commerce, NOAA, National Marine Fisheries Service, $87 \mathrm{p}$.

[28] Kraus, E.B. (1972) Atmosphere-Ocean Interaction. Oxford University Press, London, 275 p.

[29] Gill, A. (1982) Atmosphere-Ocean Dynamics. Academic Press, New York, 662.

[30] Bakun, A. (1975) Daily and Weekly Upwelling Indices, West Coast of North America, 1967-73. U.S. Department of Commerce, NOAA Tech. Rep., NMFS SSRF-693, 114 p.

[31] Bowden, K.F. (1983) Physical Oceanography of Coastal Waters. Camelot Press Ltd., Southampton, Great Britain, $302 \mathrm{p}$.

[32] Perez-Brunius, P.M., Lopez, A.P., Pares-Sierra, A. and Pineda, J. (2007) Comparison of Upwelling Indices off Baja California Derived from Three Different Wind Data Sources. 
California Cooperative Oceanic Fisheries Investigations Report, 48, 204-214.

[33] Zaytsev, O., Cervantes-Duarte, R., Montante, O. and Gallegos-Garcia, A. (2003) Coastal Upwelling Activity on the Pacific Shelf of the Baja California Peninsula. Journal of Oceanography, 59, 489-502.

[34] Argote Espinoza, M.L., Gavidia Medina, F.J. and Amador Buenrostro, A. (1991) WindInduced Circulation in Todos Santos Bay, B.C., Mexico. Atmósfera, 4, 101-115.

\section{Submit or recommend next manuscript to SCIRP and we will provide best service} for you:

Accepting pre-submission inquiries through Email, Facebook, LinkedIn, Twitter, etc. A wide selection of journals (inclusive of 9 subjects, more than 200 journals)

Providing 24-hour high-quality service

User-friendly online submission system

Fair and swift peer-review system

Efficient typesetting and proofreading procedure

Display of the result of downloads and visits, as well as the number of cited articles

Maximum dissemination of your research work

Submit your manuscript at: http://papersubmission.scirp.org/

Or contact ojms@scirp.org 